\title{
PERMOHONAN EKSEKUSI KEPADA PENGADILAN NEGERI BERKAITAN DENGAN PERJANJIAN FIDUSIA TERHADAP JAMINAN YANG DIGELAPKAN*
}

\author{
SETIA BUDI \\ Sekolah Tinggi Ilmu Hukum Putri Maharaja Payakumbuh \\ Jln. Gatot Subroto Kelurahan Tanjung Pauh Komplek Mega Saiyo Kota Payakumbuh \\ e-mail:seti4.8udi@gmail.com
}

\begin{abstract}
The execution of fiduciary guarantee execution is stipulated in Article 29 of Law Number 42 Year 1999 concerning Fiduciary Guaranty which states that execution of fiduciary guarantee execution can be done by executing executorial title, sale by public auction, or sale under the hand with agreement of both parties, but in practice sometimes found when executing fiduciary guarantees on one of its borrowers, the guarantee has been transferred and controlled by a third party without the consent of the creditor. Therefore, this paper aims to find out how the process of fiduciary fraud execution against bad debts and how the legal protection against the creditors in the credit agreement of the bank against the problem digelapkannya fidusia guarantee by the debtor party.
\end{abstract}

Keywords: Execution, Agreement, Fiduciary Guarantee.

\section{Abstract}

Pelaksanaan eksekusi jaminan fidusia diatur dalam Pasal 29 Undang-Undang Nomor 42 Tahun 1999 tentang Jaminan Fidusia yang menyatakan bahwa pelaksanaan eksekusi jaminan fidusia dapat dilakukan dengan cara pelaksanaan titel eksekutorial, penjualan melalui pelelangan umum, atau penjualan di bawah tangan dengan persetujuan kedua belah pihak, namun dalam prakteknya terkadang ditemukan ketika aka melakukan eksekusi terhadap jaminan fidusia pada salah satu debiturnya, jaminan tersebut ternyata telah beralih dan dikuasai oleh pihak ketiga tanpa persetujuan dari pihak kreditur. Oleh karena itu, tulisan ini bertujuan untuk mengetahui bagaimana proses eksekusi jaminan fidusia yang digelapkan terhadap kredit macet dan bagaimana perlindungan hukum terhadap pihak kreditur dalam perjanjian kredit bank terhadap masalah digelapkannya benda jaminan fidusia oleh pihak debitur.

Kata kunci : Eksekusi, Perjanjian, Jaminan Fidusia.

* Naskah diterima: 07 Sebtember 2017, direvisi: 20 Sebtember 2017, disetujui untuk terbit: 27 Sebtember 2017 
Setia Budi: Permohonan Eksekusi Kepada Pengadilan Negeri Berkaitan Dengan Perjanjian...

\section{PENDAHULUAN}

Pelaksanaan eksekusi jaminan fidusia diatur dalam Pasal 29 Undang-Undang Nomor 42 Tahun 1999 tentang Jaminan Fidusia yang menyatakan bahwa pelaksanaan eksekusi jaminan fidusia dapat dilakukan dengan cara pelaksanaan titel eksekutorial, penjualan melalui pelelangan umum, atau penjualan di bawah tangan dengan persetujuan kedua belah pihak, namun dalam prakteknya terkadang ketika akan melakukan eksekusi terhadap jaminan fidusia pada salah satu debitur, jaminan tersebut ternyata telah beralih dan dikuasai oleh pihak ketiga tanpa persetujuan dari pihak bank.

Pihak kreditur yang dalam perjanjian kreditnya tidak menggunakan jasa asuransi, tentu akan menderita kerugian apabila benda yang dijadikan jaminan tidak bisa dieksekusi. Padahal pada Undang-Undang Jaminan Fidusia sudah dijelaskan bahwa Sertifikat Jaminan Fidusia memiliki kekuatan eksekutorial yang setara dengan putusan pengadilan yang telah berkekuatan hukum tetap.

Perbuatan debitur tersebut jelas bertentangan dengan Pasal 23 ayat (2) Undang-Undang Nomor 42 Tahun 1999 tentang Jaminan Fidusia yang menyatakan bahwa Pemberi Fidusia dilarang mengalihkan, menggadaikan, atau menyewakan kepada pihak lain benda yang menjadi objek jaminan fidusia yang tidak merupakan benda persediaan, kecuali dengan persetujuan tertulis terlebih dahulu dari penerima fidusia.

\section{METODE PENELITIAN}

Penelitian ini menggunakan metode yuridis empiris yang mana dalam penelitian ini membahas tentang permohonan eksekusi kepada Pengadilan Negeri berkaitan dengan perjanjian fidusia terhadap jaminan yang digelapkan.

\section{HASIL DAN PEMBAHASAN}

Pelaksanaan pemberian jaminan fidusia pada umumnya dimulai dari proses pengajuan permohonan kredit oleh calon debitur kepada pihak bank atau kreditur, dan kemudian permohonan tersebut diproses, diperiksa kelengkapan persyaratan dan jaminan serta dilakukan survei calon debitur hingga nantinya permohonan tersebut disetujui dan dilakukan penandatanganan perjanjian kreditnya.

Perjanjian kredit antara pihak kreditur atau bank dengan debitur, akan diikuti dengan perjanjian pembebanan jaminan fidusia yang akan dibuat dihadapan Notaris. Akta jaminan fidusia tersebut didaftarkan hingga diterbitkanlah Sertifikat Jaminan Fidusia, yang mempunyai kekuatan eksekutorial sama dengan putusan pengadilan yang telah memperoleh kekuatan hukum tetap.

Pelaksanaan pemberian jaminan fidusia harus sesuai dengan aturan yang berlaku pada Pasal 5 ayat (1) UndangUndang Nomor 42 Tahun 1999 tentang Jaminan Fidusia yang menyatakan bahwa pembebanan benda dengan jaminan fidusia dibuat dengan akta notaris dalam bahasa Indonesia dan merupakan akta jaminan fidusia. Pasal 11 Undang-Undang 
Jaminan Fidusia tersebut juga menerangkan bahwa benda yang dibebani dengan jaminan fidusia wajib didaftarkan. Undang-Undang Nomor 42 Tahun 1999 tentang Jaminan Fidusia, mengatur tentang pembebanan dan pendaftaran jaminan fidusia. Pembebanan dan pendaftaran jaminan fidusia diatur pada Pasal 4 sampai Pasal 18 Undang-Undang Jaminan Fidusia.

Akta Jaminan Fidusia biasanya ditandatangani bersamaan dengan Perjanjian Kredit antara debitur dengan pihak bank atau kreditur, kemudian debitur juga menandatangani Surat Kuasa Pembebanan Jaminan Fidusia yang isinya menyatakan bahwa pihak kreditur mewakili kepentingan pemberi kuasa (debitur) melakukan tindakan hukum untuk mendaftarkan jaminan fidusia ke Kantor Pendaftaran Fidusia, hal ini sesuai dengan Pasal 11 dan Pasal 12 UndangUndang Jaminan Fidusia yang menyatakan bahwa benda yang dibebani dengan jaminan fidusia wajib didaftarkan, dan pendaftaran jaminan fidusia dilakukan pada Kantor Pendaftaran Fidusia.

Perjanjian kredit antara pihak bank atau kreditur dengan debiturnya, dilakukan karena para pihak tersebut telah sepakat dan tunduk pada isi perjanjian. Kepercayaan yang diberikan oleh pihak bank atau kreditur berupa kepercayaan dalam arti pihak debitur akan membayar hutangnya tepat pada waktunya, hal ini sebagaimana Teori Kepercayaan yang dikemukakan oleh Schoordijk (Vertrouwens theorie). Schoordijk berpendapat bahwa kekuatan mengikat perjanjian harus dicari dalam kepercayaan yang dimunculkan atau dibangkitkan pada pihak lawan.

Pemberian kredit berarti memberikan kepercayaan kepada debitur oleh kreditur, meskipun kepercayaan tersebut mengandung risiko yang tinggi, oleh karena itu debitur umumnya diwajibkan menyediakan jaminan berupa agunan (kebendaan tertentu) yang dapat dinilai dengan uang, berkualitas tinggi, dan mudah dicairkan yang nilainya minimal sebesar jumlah utang yang diberikan kepadanya. Jaminan tersebut merupakan sarana perlindungan bagi keamanan kreditur, yaitu kepastian atas pelunasan utang debitur atau pelaksanaan suatu prestasi oleh debitur atau oleh penjamin debitur. Keberadaan jaminan merupakan persyaratan untuk memperkecil resiko bank dalam menyalurkan kredit, oleh karena itulah muncul perjanjian tambahan berupa perjanjian jaminan secara fidusia.

Istilah fidusia berasal dari bahasa Belanda, yaitu fiducie, sedangkan dalam bahasa Inggris disebut fiduciary transfer of ownership, yang artinya kepercayaan. Dalam berbagai literatur, fidusia lazim disebut dengan istilah eigendom overdract (FEO), yaitu penyerahan hak milik berdasarkan atas kepercayaan. Pengalihan hak kepemilikan adalah pemindahan hak kepemilikan dari pemberi fidusia kepada penerima fidusia atas dasar kepercayaan, dengan syarat bahwa benda yang menjadi 
Setia Budi: Permohonan Eksekusi Kepada Pengadilan Negeri Berkaitan Dengan Perjanjian...

objeknya tetap berada di tangan pemberi fidusia. ${ }^{1}$

Pada pelaksanaan pemberian jaminan fidusia, hak kepemilikan yang berpindah adalah berupa jaminan yang diberikan oleh debitur kepada pihak bank, misalnya berupa kepemilikan kendaraan roda 4 (empat), dan objeknya tersebut tetap berada di tangan debitur. Sebagaimana dijelaskan pada bagian dari Pasal 15 Perjanjian Kredit salah satu bank, yang menyatakan bahwa penyerahan hak milik atas dasar kepercayaan telah diterima oleh pihak bank dan oleh pihak bank diserahkan kembali kepada pihak debitur sesuai dengan hukum fiduciare, untuk dipakai secara cuma-cuma atau dipinjam oleh pihak debitur.

Proses eksekusi jaminan fidusia yang digelapkan terhadap kredit macet diawali dengan pemberian surat peringatan secara bertahap sebanyak 3 (kali) kepada pihak debitur, namun karena masih tidak ada itikad baik dari debitur maka pihak bank akhirnya memutuskan untuk mengeksekusi objek jaminan fidusia tersebut. Permasalahan muncul ketika akan melakukan eksekusi jaminan ternyata jaminan tersebut telah digelapkan oleh pihak debitur, dengan mengalihkannya pada pihak ketiga tanpa ada persetujuan dari pihak bank atau kreditur, oleh karena itulah pihak bank melalui kuasa hukumnya mengajukan permohonan eksekusi kepada Ketua Pengadilan Negeri setempat. Pada

1 Salim HS, 2011, Perkembangan Hukum Jaminan Di Indonesia, PT. Raja Grafindo Persada, Jakarta, Hlm. 55-56 persidangan pertama dengan agenda mediasi, kedua belah pihak akhirnya memutuskan untuk menyelesaikan permasalahan ini dengan jalan damai.

Dalam proses eksekusi jaminan fidusia dilaksanakannya sesuai dengan Pasal 15, Pasal 29 ayat (1) huruf a, dan Pasal 30 Undang-Undang Jaminan Fidusia, namun pihak bank yang tidak mendapatkan itikad baik dari debitur, dengan berpindahnya dan dikuasainya objek jaminan fidusia oleh pihak ketiga, akhirnya mengajukan permohonan eksekusi kepada Ketua Pengadilan Negeri setempat agar tercapai keadilan dan kepastian hukum dalam pelunasan utang debitur. Pasal 20 Undang-Undang Jaminan fidusia sudah mengatur bahwa jaminan fidusia tetap mengikuti benda yang menjadi objek jaminan fidusia dalam tangan siapapun benda tersebut berada, kecuali pengalihan atas benda persediaan yang menjadi objek jaminan fidusia.

Perjanjian kredit antara pihak kreditur dan debitur memuat hak-hak dan kewajiban-kewajiban yang sudah disepakati diawal perjanjian. Perjanjian kredit yang dilakukan oleh para pihak terjadi karena para pihak telah sepakat dan tunduk pada isi perjanjian. Kepercayaan yang diberikan oleh pihak kreditur berupa kepercayaan dalam arti pihak debitur akan membayar hutangnya tepat pada waktunya ternyata tidak terlaksana, dan ketika eksekusi akan dilaksanakan, objek jaminan fidusianya pun juga telah beralih dan dikuasai oleh pihak ketiga. Pihak bank dalam hal ini 
tentunya ingin memperoleh kepastian hukum atas masalah wanprestasi yang dilakukan oleh debitur. Kepastian hukum disini berarti dapat diputuskan mengenai eksekusi objek jaminan fidusia yang telah digelapkan oleh debitur.

Jika dianalisis berdasarkan Teori Kepercayaan, maka pihak debitur tidak lagi menjaga apa yang sudah dipercayakan diawal, padahal dalam Pasal 1338 ayat (1) KUHPerdata dijelaskan bahwa perjanjian yang dibuat secara sah berlaku sebagai Undang-Undang bagi mereka yang membuatnya. Artinya, perjanjian yang dibuat oleh para pihak ditentukan isinya oleh para pihak dan tidak boleh bertentangan dengan peraturan perundang-undangan, ketertiban umum dan kesusilaan. Selain itu, ketentuan ini memiliki suatu kekuatan mengikat karena perjanjian yang dibuat memiliki kekuatan mengikat layaknya sebagai suatu undang-undang bagi para pihak yang membuatnya.

Suatu perjanjian juga harus
dilandaskan pada itikad baik,
sebagaimana dijelaskan dalam ketentuan
Pasal 1338 ayat (3) KUHPerdata, bahwa suatu perjanjian harus dilaksanakan dengan itikad baik. Asas itikad baik ini merupakan pembatasan asas kebebasan berkontrak. Para pihak dalam membuat perjanjian tidak bermaksud hendak "membohongi", "menipu", atau "mencurangi" lawannya. Asas itikad baik juga merupakan landasan utama dari dan dalam membuat dan melaksanakan sebuah perjanjian, sehingga perjanjian itu nantinya dapat dilaksanakan dengan sebaik-baiknya oleh para pihak yang bersangkutan dalam perjanjian tersebut. ${ }^{2}$

Itikad baik ini dapat dibedakan atas itikad baik pada waktu akan mengadakan hubungan hukum atau perjanjian, dan itikad baik pada waktu melaksanakan hak-hak dan kewajiban yang timbul dari hubungan hukum atau perjanjian tersebut. Itikad baik pada waktu akan mengadakan hubungan hukum atau perjanjian tidak lain adalah perkiraan dalam hati sanubari yang bersangkutan bahwa syarat-syarat yang diperlukan untuk mengadakan hubungan hukum atau perjanjian secara sah menurut hukum sudah terpenuhi semuanya. Inilah yang dinamakan dengan kejujuran. Adapun itikad baik pada waktu melaksanakan hak-hak dan kewajiban yang timbul dari suatu hubungan hukum atau perjanjian tidak lain daripada itikad baik pada waktu melaksanakan hubungan hukum atau perjanjian yang telah dibuat tersebut.

Itikad baik juga terletak pada hati sanubari manusia yang selalu ingat, bahwa dalam melaksanakan perjanjian harus mengindahkan norma-norma kepatutan dan keadilan, dengan menjauhkan diri dari perbuatan-perbuatan yang mungkin menimbulkan kerugian terhadap pihak lawan. Suatu perjanjian yang dilaksanakan dengan itikad baik akan tercermin pada perbuatan-perbuatan nyata pelaksanaan perjanjian, dan ini akan memberikan ukuran objektif tentang ada tidaknya itikad baik itu.

2 Djoni S. Gozali dan Rachmadi Usman, 2012, Hukum Perbankan, Sinar Grafika, Jakarta, hlm. 342 . 
Setia Budi: Permohonan Eksekusi Kepada Pengadilan Negeri Berkaitan Dengan Perjanjian...

Dalam perjanjian kredit pada bank selain adanya itikad baik ini, sebelum suatu fasilitas kredit diberikan, maka bank harus merasa yakin bahwa kredit yang diberikan benar-benar akan kembali. Keyakinan tersebut diperoleh dari hasil penilaian kredit sebelum kredit tersebut disalurkan.

Bentuk perlindungan hukum terhadap pihak dalam perjanjian kredit bank terhadap masalah digelapkannya benda jaminan fidusia oleh pihak debitur selain terdapat pada Undang-Undang Nomor 42 Tahun 1999 tentang Jaminan Fidusia, juga dapat kita lihat pada aturan-aturan yang telah tercantum pada Akta Jaminan Fidusia yang dibuat oleh Notaris, yang telah ditandatangani oleh pihak bank dan debitur dihadapan notaris, pada intinya telah mengatur hal-hal yang dapat dimanfaatkan oleh pihak kreditur sebagai perlindungan hukum apabila terjadi masalah-masalah dikemudian hari, disamping itu Sertifikat Jaminan Fidusianya juga dapat memberikan perlindungan bagi penerima fidusia berupa hak didahulukan dari kreditur lainnya atas pelunasan utang debitur apabila debitur melakukan cidera janji.

Sertifikat Jaminan Fidusia ini juga dapat dipersamakan dengan putusan pengadilan yang telah memperoleh kekuatan hukum tetap yang mana samasama mempunyai kekuatan eksekutorial. Jika pada akhirnya aturan yang seharusnya bisa memberikan kepastian dan perlindungan hukum bagi pihak kreditur tidak bisa didapatkan, maka karena itulah pihak kreditur dapat mengambil jalan untuk mengajukan permohonan eksekusi pada Pengadilan Negeri setempat.

\section{SIMPULAN}

1. Pelaksanaan pemberian jaminan fidusia pada suatu bank pada umumnya dimulai dari proses pengajuan permohonan kredit oleh calon debitur kepada pihak bank dan kemudian permohonan tersebut diproses, diperiksa kelengkapan persyaratan dan jaminan serta dilakukan survei calon debitur hingga nantinya permohonan tersebut disetujui dan dilakukan penandatanganan perjanjian kreditnya. Perjanjian kredit akan diikuti dengan perjanjian pembebanan jaminan fidusia yang akan dibuat dihadapan Notaris. Akta jaminan fidusia tersebut didaftarkan hingga diterbitkanlah Sertifikat Jaminan Fidusia, yang mempunyai kekuatan eksekutorial sama dengan putusan pengadilan yang telah memperoleh kekuatan hukum tetap.

2. Proses eksekusi jaminan fidusia yang digelapkan terhadap kredit macet diawali dengan pemberian surat peringatan secara bertahap sebanyak 3 (kali) kepada pihak debitur, namun jika masih tidak ada itikad baik dari debitur maka pihak bank atau kreditur dapat mengeksekusi objek jaminan fidusia tersebut. Permasalahan muncul ketika akan melakukan eksekusi jaminan ternyata jaminan tersebut telah digelapkan oleh pihak debitur, dengan mengalihkannya pada pihak 
ketiga tanpa ada persetujuan dari bank atau kreditur, oleh karena itulah pihak bank melalui kuasa hukumnya mengajukan permohonan eksekusi kepada Ketua Pengadilan Negeri setempat.

3. Bentuk perlindungan hukum terhadap pihak kreditur dalam perjanjian kredit bank terhadap masalah digelapkannya benda jaminan fidusia oleh pihak debitur selain terdapat pada UndangUndang Nomor 42 Tahun 1999 tentang Jaminan Fidusia, juga dapat kita lihat pada aturan-aturan yang telah tercantum pada Akta Jaminan Fidusia yang dibuat oleh Notaris, yang telah ditandatangani oleh pihak bank dan debitur dihadapan notaris, pada intinya telah mengatur hal-hal yang dapat dimanfaatkan oleh pihak kreditur sebagai perlindungan hukum apabila terjadi masalah-masalah dikemudian hari, disamping itu Sertifikat Jaminan Fidusianya juga dapat memberikan perlindungan bagi penerima fidusia berupa hak didahulukan dari kreditur lainnya atas pelunasan utang debitur apabila debitur melakukan cidera janji. Sertifikat Jaminan Fidusia ini juga dapat dipersamakan dengan putusan pengadilan yang telah memperoleh kekuatan hukum tetap yang mana sama-sama mempunyai kekuatan eksekutorial. Jika pada akhirnya aturan yang seharusnya bisa memberikan kepastian dan perlindungan hukum bagi pihak kreditur tidak bisa didapatkan, maka karena itulah pihak kreditur dapat mengambil jalan untuk mengajukan permohonan eksekusi pada Pengadilan Negeri setempat.

\section{SARAN}

1. Pada pelaksanaan pemberian jaminan fidusia pihak bank sebelum menyetujui pemberian kredit kepada debitur hendaknya dapat lebih teliti dan berhati-hati dalam melihat watak (character), kemampuan (capacity), modal (capital), situasi ekonomi (condition of economic) dan agunan (collateral) dari pihak debitur, hal ini dilakukan agar pihak bank dapat meminimalisir kasus kredit macet pada debitur-debiturnya.

2. Bagi pihak debitur, sebelum memutuskan untuk menandatangani Perjanjian Kredit dengan pihak bank, sebaiknya lebih dipahami isi pasal demi pasal yang terdapat pada Perjanjian Kredit tersebut. Debitur hendaknya lebih mengerti apa yang menjadi hak dan kewajiban dari masing-masing pihak, mengerti dan paham atas setiap konsekuensi yang akan diterima jika mengingkari kesepakatan yang telah diperjanjikan diawal. Jika dirasa bunga dari pinjaman nantinya akan memberatkan dikemudian hari, akan lebih baik jika modal untuk usaha diperoleh dengan pinjaman yang bunganya tidak terlalu memberatkan.

3. Dalam setiap perjanjian kredit dengan jaminan fidusia, hendaknya selalu didaftarkan Akta Jaminan Fidusianya pada Kantor Pendaftaran Fidusia agar terbit Sertifikat Jaminan Fidusia yang 
Setia Budi: Permohonan Eksekusi Kepada Pengadilan Negeri Berkaitan Dengan Perjanjian...

merupakan suatu bentuk perlindungan hukum bagi pihak kreditur. Adanya Sertifikat Jaminan Fidusia yang mempunyai kekuatan eksekutorial sama dengan putusan pengadilan yang telah berkekuatan hukum tetap, akan sangat membantu dalam proses eksekusi jaminan apabila debitur cidera janji.

\section{UCAPAN TERIMAKASIH}

Puji dan Syukur penulis ucapkan ke hadirat Allah SWT yang telah memberikan Rahmat dan Karunia-Nya, sehingga akhirnya penulis dapat menyelesaikan penulisan karya ilmiah ini yang berjudul: "PERMOHONAN EKSEKUSI KEPADA PENGADILAN NEGERI BERKAITAN DENGAN PERJANJIAN FIDUSIA TERHADAP JAMINAN YANG DIGELAPKAN".

Penulis menyadari bahwa tanpa bantuan dan dorongan dari berbagai pihak tidak mungkin karya ilmiah ini dapat diselesaikan. Oleh karena itu pada kesempatan ini dengan segala kerendahan hati, penulis ingin mengucapkan terimakasih dan penghargaan yang sebesar-besarnya kepada:

1. Bapak Dr. Eviandi Ibrahim S.H., M.Hum selaku Ketua Sekolah Tinggi Ilmu Hukum Putri Maharaja Payakumbuh

2. Seluruh rekan-rekan Dosen Sekolah Tinggi Ilmu Hukum Putri Maharaja yang tidak dapat penulis sebutkan satu-persatu.

\section{DAFTAR PUSTAKA}

Agus Yudha Hernoko, Hukum Perjanjian: Asas Proporsionalitas dalam Kontrak Komersial, Jakarta: Kencana, 2011.

Djoni S. Gozali dan Rachmadi Usman, Hukum Perbankan, Jakarta: Sinar Grafika, 2012

Handri Raharjo, Hukum Perjanjian di Indonesia, Yogyakarta: Pustaka Yustisia, 2009.

Herowati Poesoko, Parate Executie Obyek Hak Tanggungan, Yogyakarta: Laksbang Pressindo, 2008.

Kartini Muljadi dan Gunawan Widjaja, Seri Hukum Harta Kekayaan Hak Tanggungan, Jakarta: Prenada Media Group, 2008.

Lamintang, Delik-Delik Khusus Kejahatan Terhadap Harta Kekayaan, Jakarta: Sinar Grafika, 2009.

Lexy J Moeleng, Metodologi Penelitian Kualitatif, Bandung: Remaja Rosda Karya, 2005.

Muhammad Djumhana, Hukum Perbankan di Indonesia, Bandung: PT. Citra Aditya Bakti, 2011.

Munir Fuady, Pengantar Hukum Bisnis, Menata Bisnis Modern di Era Global, Bandung: PT. Citra Aditya Bakti, 2008.

M. Bahsan, Hukum Jaminan dan Jaminan Kredit Perbankan Indonesia, Jakarta: PT Raja Grafindo Persada.

M. Yahya Harahap, Ruang lingkup Permasalahan Eksekusi Bidang Perdata, Jakarta: PT Gramedia, 1991.

Peter Mahmud Marzuki, Penelitian Hukum, Jakarta: Prenada Media, 2005. 
Jurnal Cendekia Hukum: Vol. 3, No 1, September 2017

Rachmadi Usman, Hukum Jaminan Keperdataan, Jakarta: Sinar Grafika, 2008.

Rudyanti Dorotea Tobing, Hukum Perjanjian Kredit: Konsep

Perjanjian Kredit Sindikasi yang Berasaskan Demokrasi Ekonomi, Yogyakarta: Laksbang Grafika, 2014.

Salim HS, Perkembangan Hukum Jaminan Di Indonesia, Jakarta: PT. Raja Grafindo Persada, 2011.

Soerjono Soekanto, Pengantar Penelitian Hukum, Jakarta: UI Press, 2012.

Subekti, Hukum Perjanjian, Jakarta: Intermasa, 2010.
Sudikno Mertokusumo, Hukum Acara Perdata Indonesia, Yogyakarta: Liberty, 2006.

Thomas Suyatno, dkk, Kelembagaan Perbankan, Jakarta: PT. Gramedia Pustaka Utama, 2003.

Wiryono Projodikoro, Asas-Asas Hukum Perjanjian, Bandung: Mandar Maju, 2004.

\section{Peraturan Perundangan-undangan:}

Kitab Undang-Undang Hukum Perdata (BW)

Kitab Undang-Undang Hukum Pidana 